\title{
AN OVERVIEW OF TREATMENT OF BRACKISH WATER USING SOLAR STILLS
}

\author{
Sudhanshu S. Kamat \\ Department of General Engineering \\ Institute of Chemical Technology, Mumbai, \\ Maharashtra, India - 400019
}

\begin{abstract}
Solar desalination technologies are becoming popular among the scientific community for the production of fresh water from the brackish water. Membrane technologies are expensive to be implemented on small scale. Solar stills have simple working principle and there is low cost associated with it. Varied configurations and modifications have been implemented to improve the performance of solar stills. Thermodynamic analysis has also been done for the same. However, it is important to also optimize various combinations of the operating parameters, including the cost-benefit analysis associated with it. This paper focuses on the review of the effects of various geometric and operating parameters, and also optimizing the thermodynamics to improve the performance of solar still.
\end{abstract}

Keywords - Solar Still, Brackish, Distillate, TDS

\section{INTRODUCTION}

The global demand for the supply of potable water has regularly increased due to the population explosion, effects of climate change and also the geography of our planet. Several countries will face water crisis of severe nature and also the situation will be critical in the regions which already face fresh water shortage issues. Groundwater is a replenishable natural resource in India, however the quality of groundwater varies depending on the geographical conditions. Though groundwater reserves are fresh in most of the areas of India, the semi-arid zones of Rajasthan and the coastal regions have found to be brackish in nature, which is in indication of high total dissolved solids. The fluoride contaminated groundwater have been extensively found beyond the permissible limits in vast areas of Haryana, Andhra Pradesh, Rajasthan and in some parts of Uttar Pradesh, Punjab, Karnataka, Madhya Pradesh and Tamil Nadu. In the north-eastern regions, the content of iron has been widely found to be above the permissible limits. Groundwater contamination has been observed to be localized in certain pockets of industrial zones. These problems have led to the need for the treatment of groundwater before it is fit for consumption.

The characteristics of groundwater and the properties associated with it makes it imperative to be treated for the removal of harmful contaminants. There are various

\author{
Dilip D. Sarode \\ Department of General Engineering \\ Institute of Chemical Technology, Mumbai, \\ Maharashtra, India - 400019
}

technologies such as desalination, electrodialysis, capacitive deionization, reverse osmosis and zeolite softening which can be the alternatives to treat the groundwater which is brackish in nature. However, the efficiency of removal of fluorides and arsenic is very less to meet the compliance. This leads to the use of alternative scientific principles in which heat can be used to separate the contaminants from the brackish water. The technologies like single stage and multiple effect evaporator have provided a considerable scope to treat the brackish water, however there is high capital and maintenance cost associated with these technologies. This provides a wide scope to use sustainable alternatives such as use of solar thermal energy to treat the brackish water.
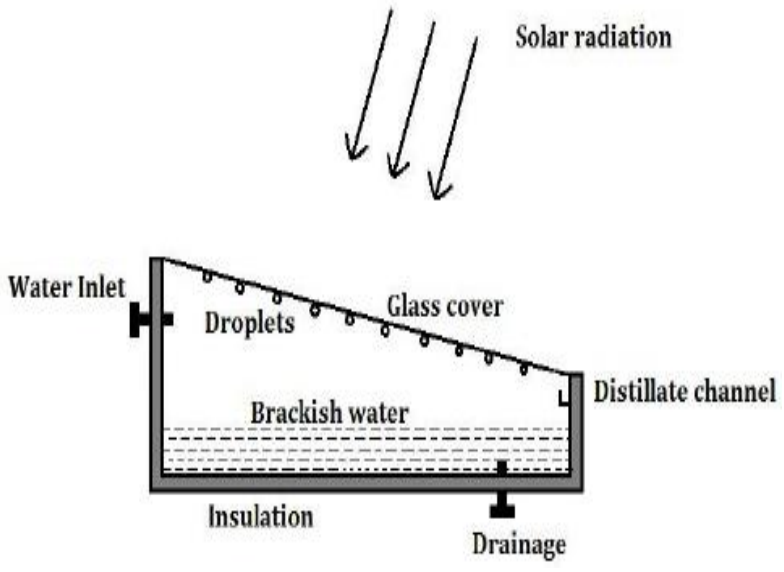

Fig. 1. Schematic diagram of a conventional solar still

A Solar Still works on the basic principle of solar distillation which comprises of evaporation and condensation of water by virtue of heat of sun. A schematic diagram is shown in Fig. 1. It consists of an absorber surface on which brackish water is placed, an insulated frame to hold the brackish water and an inclined glass cover on top for transfer of heat energy. The brackish water is the influent to be treated in this system for the production of the distillate which is the water vapour condensed on the inner surface of the glass cover. At the lower end of the inner surface of the glass cover, a channel is provided to collect the distillate. 


\section{International Journal of Engineering Applied Sciences and Technology, 2021 \\ Vol. 6, Issue 3, ISSN No. 2455-2143, Pages 199-203 \\ Published Online July 2021 in IJEAST (http://www.ijeast.com)}

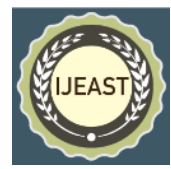

The conventional solar stills have been modified by various researchers to improve the yield of the distillate from the brackish water. This has been done by modifying various factors such as absorber surface, glazing material, insulation material, external and internal geometrical configuration, depth of the brine in the still, wind factor, heat losses and the difference between the absorber and condenser surface. This has provided a wide scope for researchers to explore various modifications which can be used to treat brackish water with higher distillate yield.

\section{REVIEW OF PARAMETERS AFFECTING THE PERFORMANCE OF SOLAR STILLS}

The solar stills are majorly classified into active and passive solar stills. The conventional solar still is a passive still which works without water pump, fan or any electricity driven element. It also does not contain any solar collector to heat the water. The design is simple and contains low cost material and low operation cost. However, the major drawback is low distillate production per unit area. Due to the constraint of area, it becomes imperative for the researchers to critically analyze the factors which affect the performance of the solar stills. These factors can then be considered to modify the designs of solar stills. These types of solar stills include simple effect basin type solar still. Various researchers have worked on modification of conventional solar stills in order to improve the performance of the still.

\section{A. Absorber Surface}

The absorber surface is an important component of a solar still unit. It absorbs the solar radiation incident on it through the glazing material and transfers the heat to the brackish water. The coating on the absorber surface should have high absorptivity and poor emissivity in order to attain a higher temperature of brackish water. The sides and the bottom of the absorber are insulated to reduce the heat loss due to conduction.

Use of porous media and wick materials have been explored to be used a better absorbing materials to augment the yield of fresh water distillate. The principle behind using the wick materials is that due to the capillary action, there is increase in the effective surface area of the brackish water, thereby enhancing the radiative and convective heat transfers. The property of wick ensures that the water gets transmitted through the evaporation surface more readily, thereby exposing it the solar intensity. Rashidi et. al. [1] had used reticular porous media consisting of black sponge rubber. They found that about $18 \%$ more distilled water was produced in comparison to the conventional still. Nafey et. al. [2] had used a perforated floating absorber plate which was painted with black paint for the experimental work. There were perforations of $0.5 \mathrm{~mm}$ diameter made on this absorber plate. Many other researchers [3-6] have also used matt black polymethyl methacrylate, blackened jute wick with ordinary black paint, charcoal granules as well. Abdallah et. al. [7] studied the effects of different heat absorbing materials on the performance of the solar still. They found that the coated metallic wiry sponge, uncoated metallic wiry sponge and the black rock, when used as heat absorbing materials, enhanced the yield of distillate production by $28 \%, 48 \%$ and $60 \%$ respectively, in comparison with the conventional type of still. Bassam et. al. [8] studied the effect of sponge cubes as absorbing material. They found that the production enhanced to $273 \%$ in comparison to the still without the use of sponge. The principle behind selection of material for the absorber surface must be to trap the heat energy received from the solar radiation, and use it efficiently to heat the brackish water by conductive heat transfer, and minimize the heat losses due to convective transfer.

\section{B. Glazing Material -}

The basic function of a glazing material in the solar still unit is to admit the solar radiation to its maximum possibility and also to minimize the heat loss from the absorber surface in the upward direction. In majority of the work which has been done, glass has been used as an ideal glazing material because of its high transmissivity for the incident solar radiation with short wavelength. For the longer wave of heat radiation with wavelength ranging from 5 to $50 \mu \mathrm{m}$, which is found to be emitted by the absorber plates, the glass acts as an opaque material, thereby resisting the heat loss from inside the still in the upward direction. However, this needs detail analysis of the glass materials, in order to ensure that whatever heat losses exist from the glazing material, is minimized to negligible amount, to improve the performance of the solar still [9].

\section{Thermal Insulation-}

Thermal insulation is the most critical parameter which affects the performance of a solar still. The basic mechanism of the working of a solar still is based on the amount of absorbed heat and maximum transfer of the heat to the brackish water. Literatures have been documented for the use of glass wool, rice husks, polystyrene and foams which can be used as insulating materials for the solar stills.

Nafey et. al. [10] had used foam as the insulating material of $4 \mathrm{~mm}$ thickness and silicon rubber as a sealant. Varol and Yazar [11] had used polyester as insulation. Cappelletti [12] had used polystyrene for insulating the sides and the bottom of the basin; whereas Kabeel [13] had used glass wool of thickness $5 \mathrm{~cm}$ for the insulation purpose. On the other hand, Velmurugan et. al. [14] had used readily available sawdust as insulation material.

There is a dearth of alternatives for materials that can be used for thermal insulation, however, it is important for the researchers and fabricators to ensure that the thermal insulators provided have a considerable durability, in order to maintain the performance of the solar still, so that the heat losses can be minimized to the best possible extent. 


\section{International Journal of Engineering Applied Sciences and Technology, 2021 \\ Vol. 6, Issue 3, ISSN No. 2455-2143, Pages 199-203 \\ Published Online July 2021 in IJEAST (http://www.ijeast.com)}

\section{Geometry-}

Among the various factors which affect the performance of the solar still, the geometrical design variations and spatial configuration remains as one of the popularly researched parameter because of the vast scope of modifications which can be done, depending on the meteorological conditions of a certain place. And in the process, it needs a systematic investigation of the geographical features of the location of solar still.

El-Sebaii et. al. [15], as shown in Fig. 2, had designed a baffle suspended absorber plate in the single basin solar still to ensure preheating of feed water at a faster rate.

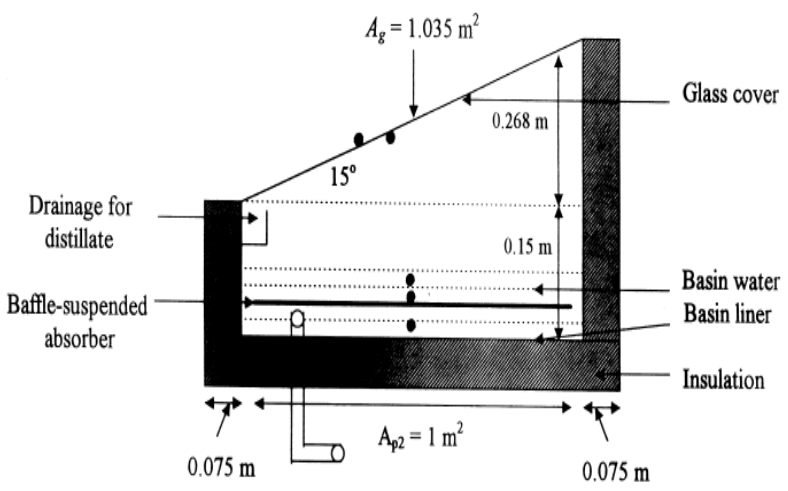

Fig. 2. Schematic diagram of the single slope single basin solar still with baffle suspended absorber

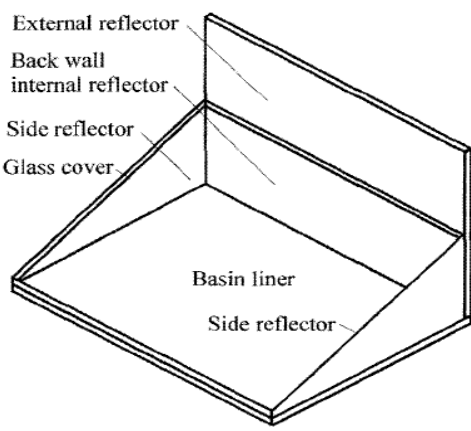

Fig. 3. Schematic diagram of basin type still with reflectors

Tanaka and Nakatake [16] had installed a solar still with internal and external reflectors as shown in Fig. 3 and they found $48 \%$ increase in the distillate yield. Subsequently, an external condenser consisting of four sidewalls was installed to enhance the distillate output.

Kabeel [17] designed a concave internal surface of the absorber, as shown in Fig. 4, to reduce the shading effect which is present in the conventional type. Moreover, the use of glass covers on four sides of the still reduces the shading effect in comparison with the conventional solar still.
Ahsan. et. al. [18] designed a tubular solar still, as shown in Fig. 5., and they found that the productivity of the distillate yield can be enhanced by this geometrical configuration due to the locus formed by the apparent positions of sun and earth.

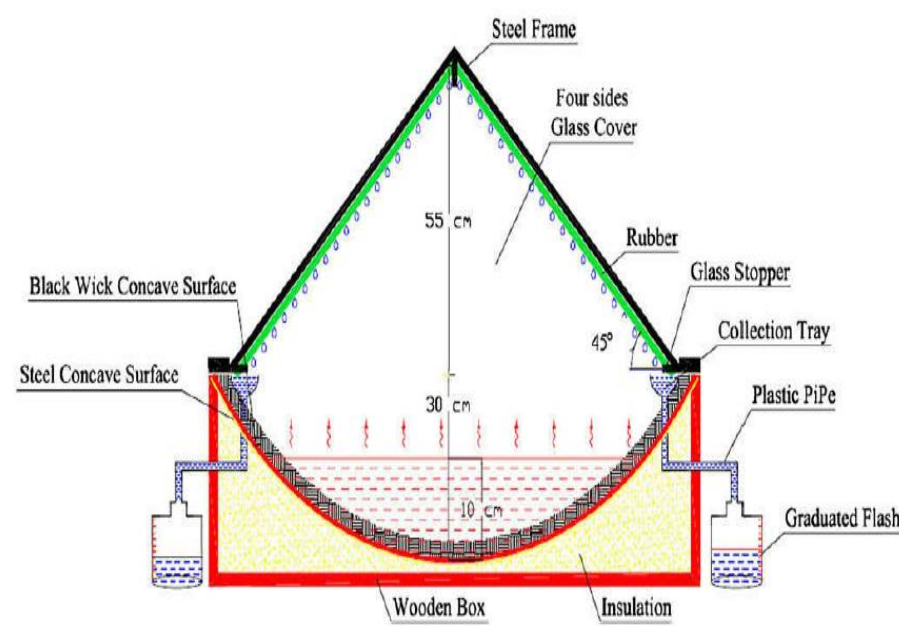

Fig. 4. Schematic diagram of concave solar still with four side glass cover
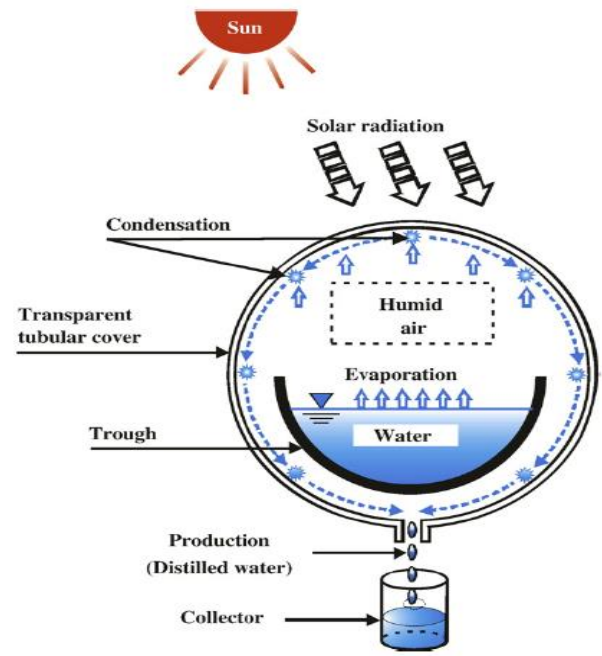

FIG. 5. Production principle of a Tubular Solar Still

\section{E. Brine Depth-}

Brine depth is one of the key factors which will affect the rate at which the condensation of water vapour will take place on the inner glass surface. Lesser the vertical distance between the brackish water surface and the glass cover, faster is the rate of condensation because lesser time will be required by the water vapour to reach the inner glass cover surface. This principle broadens the scope of modifying the internal configuration of the absorber surface, in case of a conventional solar still. 


\section{International Journal of Engineering Applied Sciences and Technology, 2021 \\ Vol. 6, Issue 3, ISSN No. 2455-2143, Pages 199-203 \\ Published Online July 2021 in IJEAST (http://www.ijeast.com)}

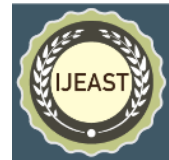

Ismail [19] had designed and studied the performance of a hemispherical solar still by varying the brine depths. He found that for an increase of brine depth from $12 \mathrm{~mm}$ to $18 \mathrm{~mm}$, the conversion ratio of brackish water to distillate reduced drastically from $49.4 \%$ and $15.4 \%$. This concluded that even a minor increase in brine depth can be critical in reducing the performance of a solar still.

Alaudeen et. al. [20] maintained minimum depth in the conventional solar still by providing a stepped type basin. They found that this modification in the internal configuration of the still reduced the effective depth of brine, thereby augmenting the distillate yield and improving the performance of the solar still.

\section{F. Wind -}

Higher wind speed causes fall in the temperature of the glass cover because of the increase in the convective heat loss from the glass cover to the ambient atmosphere. This increases the temperature difference between the glass cover and the brackish water, which leads to increased productivity of the distillate. Though this is one of the factors affecting the performance of the solar stills, it is also an uncontrollable parameter as it is nearly impossible to control the wind speed which is also varying at different times of the day. The higher wind speed tends to increase the condensation rates at the still cover, thereby increasing the distillate yield.

\section{G. Heat Transfer and Losses-}

The heat transfer mechanism inside a solar still is very important to design an efficient solar still. Moreover, it is also imperative to study the heat losses from the glass cover, bottom and the sides of the basin, to ensure that insulation is provided to minimize these losses to negligible amount. Convection, conduction and radiation are the three ways in which losses from solar still can occur. There is internal heat transfer inside the solar still which consists of evaporation, radiation and convection. Inside the solar distillation, evaporative heat transfers and convective heat transfer occurs simultaneously.

Tripathi and Tiwari [21] had performed thermal modelling of passive and active solar stills for different water depths. One of the key findings of their study was that there is decrease in the internal convective heat transfer coefficient with the increasing depth of brackish water, and also due to the decrease in the temperature of brackish water.

Al-Hussaini and Smith [22] had enhanced the productivity of solar still using vacuum technology. The key finding of their work was that the inhibition of vacuum inside the solar still reduces the convective heat transfer loss and increases the condensation rate significantly.

\section{ECONOMIC EvAluATION}

The viability in social life as well as the techno-economic feasibility of an engineering system is very essential. The capital cost of equipment and the running costs are influenced by factors such as feed water quality, geometry, size and the ambient weather conditions. The cost of solar still depends on the quality of insulation, glass cover, absorber plate and the material used to frame these components. The major economic benefit of solar still is that it is easy to construct, install, operate and maintain.

Kabeel [23] et. al. had reviewed various types of solar stills and performed the economic analysis. They observed that the highest cost-benefit was obtained using pyramid shaped solar still, whereas lowest cost-benefit was observed in case of modified solar stills coupled with sun tracking. Fixed annual cost, sinking fund factor, capital recovery factor, annual salvage value, average annual productivity and annual cost are the main parameters of comparison in cost-benefit analysis. Barrera [24] performed a techno-economic analysis of solar water still in Mexico and observed that distilled water production can be 3.5 times more economical than chemical water acquisition.

\section{CONCLUSION}

In this review paper, a comprehensive review of the parameters affecting the performance of solar stills for treatment of brackish water, has been emphasized. Absorber surface, glazing material, thermal insulation, geometry, brine depth, wind, heat transfer and losses, were the various factors that have reviewed in detail to critically study how these parameters affect the performance of the solar still. It is important for the researchers to focus on understanding these parameters and modify the solar stills. Moreover, the detail study of energy analysis is essential with the knowledge of heat transfer and thermodynamics to improve the performance of solar still. The prominent challenge is to decrease the loss of heat energy and increase the distillation yield per unit area. Further, experimentation and detail study is required to understand the effects and extent of various operating parameters, thermodynamics on distillate productivity and configurations along with heat transfer. In the coming future, as the demand for fresh water will increase, it will be essential to implement such low-cost technologies on a commercial scale

\section{REFERENCE}

[1] S. Rashidi, N. Rahbar, M.S. Valipour, J.A. Esfahani, "Enhancement of solar still by reticular porous media: Experimental investigation with exergy and economic analysis", Applied Thermal Engineering, Vol. 130, pp. 1341-1348, 2018.

[2] A. S. Nafey, M. Abdelkader, A. Abdelmotalip, A. A. Mabrouk, "Enhancement of solar still productivity using floating perforated black plate", Energy Convers. Management, Vol. 43, pp. 937-946, 2002. 


\section{International Journal of Engineering Applied Sciences and Technology, 2021 \\ Vol. 6, Issue 3, ISSN No. 2455-2143, Pages 199-203 \\ Published Online July 2021 in IJEAST (http://www.ijeast.com)}

[3] A. A. El-Sebaii, S. Aboul-Enein, E. El-Bialy, "Single basin solar still with baffle suspended absorber", Energy Conversion Management Vol. 41, pp. 661-675, 2000.

[4] A. E. Kabeel, "Performance of solar still with a concave wick evaporation surface", Energy, Vol. 34, pp. 15041509, 2009.

[5] H. S. Varol, A. Yazar, "A hybrid high efficiency single basin solar still", Int. J. Energy Res., Vol. 20, pp. 541546, 1996.

[6] M. Sakthivel, S. Shanmugasundaram, T. Alwarsamy, "An experimental study on a regenerative solar still with energy storage medium - Jute cloth", Desalination, Vol. 264, pp. 24-31, 2010.

[7] S. Abdallah, M. M. Abu-Khader, O. Badran, "Effect of various absorbing materials on the thermal performance of solar still”, Desalination, Vol. 242, pp. 128-137, 2009.

[8] A. K. Bassam, Abu-Hijleh, M. Hamzeh, Rababah, "Experimental study of a solar still with sponge cubes in Basin”, Energy Conversion Management, Vol. 44, pp. 1411-1418, 2003.

[9] G. N. Tiwari, Solar Energy fundamentals, design, modelling and applications, 9th edition, New Delhi, Narosa Publishing House Private Limited, 2002.

[10] A. S. Nafey, M. Abdelkader, A. Abdelmotalip A, A. A. Mabrouk, "Solar still productivity enhancement", Energy Conversion Management, Vol. 42, pp. 1401-1408, 2001.

[11] H. S. Varol and A. Yazar, "A hybrid high efficiency single basin solar still”, Int. J. Energy Res. Vol. 20, pp. 541-546, 1996.

[12] G. M. Cappelletti, "An experiment with a plastic solar still”, Desalination Vol. 142, pp. 221-227, 2002.

[13] A. E. Kabeel, "Performance of solar still with a concave wick evaporation surface", Energy, Vol. 34, pp. 15041509, 2009.

[14] V. Velmurugan, K. J. Naveen Kumar, T. Noorul Haq, K. Srithar, "Performance analysis in stepped solar still for effluent desalination", Energy, Vol. 34, pp. 1179-1186, 2009.

[15] A. A. El-Sebaii, S. Aboul-Enein, E. El-Bialy, "Single basin solar still with baffle suspended absorber", Energy Conversion Management, Vol. 41, pp. 661-675, 2000.

[16] H. Tanaka, Y. Nakatake, "Theoretical analysis of a basin type solar still with internal and external reflectors", Desalination, Vol. 197, pp. 205-216, 2006.

[17] A. E. Kabeel, "Performance of solar still with a concave wick evaporation surface", Energy, Vol. 34, pp. 15041509, 2009.

[18] A. Ahsan, K. M. S. Islam, T. Fukuhara and A. H. Ghazali, "Experimental study on evaporation, condensation and production of a new Tubular Solar Still", Desalination, Vol. 260, pp. 172-179, 2010.
[19] I. B. Ismail, "Design and performance of a transportable hemispherical solar still", Renew. Energy, Vol. 34, pp. 145-150, 2009.

[20] A. Alaudeen, K. Johnson, P. Ganasundar, A. Syed Abuthahir, K. Srithar, "Study on stepped type basin in a solar still", Journal of King Saud University-Engineering Sciences, Vol. 26, pp. 176-183, 2014.

[21] R. Tripathi, G. N. Tiwari, "Thermal modelling of passive and active solar stills for different depths of water by using the concept of solar fraction", Sol. Energy, Vol. 80, pp. 956-967, 2006.

[22] H. Al-Hussaini, I. K. Smith, "Enhancing of solar still productivity using vacuum technology", Energy Conversion Management, Vol. 36 (11), pp. 1047-1051, 1995.

[23] A. E. Kabeel, A. M. Hamed, S. A. El-Agouz, "Cost analysis of different solar still configurations" Energy Vol. 35, pp. 2901-2908, 2010.

[24] E. Barrera, "A technical and economical analysis of solar water still in Mexico", Renew. Energy, Vol. 2(4), pp. 489-495, 1992. 